\title{
A Comparison of University Academics Job Factors: Satisfaction and Dissatisfaction
}

\author{
Sujit Kumar Basak \\ Durban University of Technology, KwaZulu-Natal, South Africa \\ sujitbasakmca@gmail.com
}

\begin{abstract}
The aim of this paper is to compare the university academics job satisfaction factors and job dissatisfaction factors. This aim is achieved by identifying the factors that affect academics job satisfaction and dissatisfaction. The main results of this study were concluded by comparing the satisfaction factors and dissatisfaction factors for university academics from the existing literature. The novelty of this study is the use of a significant body of the existing literature has focused on the factors affecting university academics in terms of job satisfaction and job dissatisfaction to get the aim. The findings would help to know for university academic factors affect for satisfaction and dissatisfaction.
\end{abstract}

Keywords: Satisfaction, dissatisfaction, academics, university, comparison

\section{Introduction}

Education plays a crucial role in any of the institutional organization of a nation and it helps to develop the country (Khalid et al., 2012). According to Feder (2000), Herzberg, Mauser \& Snyderman (1959) job satisfaction factors are different from the job dissatisfaction. Employee's job satisfaction directly associated with their performance, organizational productivity, and many other issues, including turnover. When employees are not met the expectation that make employees dissatisfied. Furthermore, the dissatisfaction of employees can be resultant into the reduction of productivity in the workforce, decrease in organizational commitment and devotion as well as increase discontinuation of the job (Santhapparaj et al., 2005; Payne and Morrison, 2002; Redfern, 2005; Denizer, 2008; Gellatly, 2005; Sagie, 2002; Adenike, 2011). However, Pearson and Seiler (1983) also indicated that university academics are usually more satisfied than dissatisfied with their working environment. According to Lawler (1973) job satisfaction is only one-dimension and when employees are satisfied with work they will be happy on the other hand, if employees are dissatisfied they will be unhappy. However, Smith et al. (1969) describes that the job satisfaction is a multi-dimensional, hence there are many factors which can influence the employees work because as someone more satisfied in terms of salary but may not be satisfied in terms of supervisor behaviour or availability or promotional opportunities in the organization. Finally, the job satisfaction can also be defined as a positive or negative feeling which employees feel in terms of their work (Locke, 1976; Odom et al., 1990). According to Rosse \& Saturay (2004), "Job dissatisfaction is by definition unpleasant, and most individuals are conditioned, probably even biologically-driven, to respond to unpleasant conditions by searching for mechanisms to reduce the dissatisfaction". Job dissatisfaction is a contributing factor that directly linked to the lack of commitment and high level of absenteeism among academics (Evans, 1998). Siegel \& Lane (1982) indicated that academic job dissatisfaction comes forward when benefits such as physical and psychological from an academic's job fall into short of employees expectation.

Problem Statement: A study was examined by Việ (2013) on the faculty members of the University of Agriculture and Forestry Ho Chi Minh City (UAF) and found that the independent variables such as fiscal resources, personal growth and satisfaction, policy and administration have accounted 59\% of variance of faculty job satisfaction. Adeel et al. (2011) indicated that the job satisfaction for university academics have an influence in terms of compensation or pay that is given to each employee. Study by Ostroff (1992) found that job satisfaction directly affect organizational performance. According to Talat et al. (2012) low job satisfaction increases the absenteeism (Vroom, 1964) and turnover rates (Clark et al., 1997). In a study by Ellickson\& Logsdon (2001) concluded that adequate equipment, required resources, training opportunities, equitable workload affect academic job satisfaction. According to Smith (2007) when academics are lack support at their work place, they are not motivated to perform well in their class rooms, when academics are not satisfied with their working environment, at that point academics prefer to change or leave the profession. Denizer (2008) \& Adenike (2011) concluded, as reported by the medical doctor that, dissatisfaction affect among academics which resultant to neuroses: insomnia, 
headache and emotional aberration, and psychological stress and disappointment. Zembylas (2004) also indicated that academic job dissatisfaction is worrisome.

Research Question: What are the important factors that affect university academics in terms of job satisfaction and job dissatisfaction?

Aims and Objectives: The aim of this study is to compare university academics job factors in terms of what factors include university academic job satisfaction and job dissatisfaction. This aim is achieved through the specific objectives: to identify which factors are more affect in terms of job satisfaction and dissatisfaction for university academics.

Theoretical Framework: This research is grounded within the theoretical framework which is proposed by Herzberg et al. (1959) on the job satisfaction and dissatisfaction factor. According to this theoretical framework the job satisfaction has got five dimensions such as achievement, recognition, work itself, responsibility, and advancement. On the other hand job dissatisfaction has also got five dimensions such as policy and administration, supervision, salary, interpersonal relations, and working conditions.

\section{Literature Review}

The aim of this section is to present existing literature on the comparison of university academics job satisfaction and dissatisfaction factors. Noordin and Jusoff (2009) indicated that in higher education job satisfaction of academics results in healthy and positive climate of the university. The positive climate of the university not only increases the academics job satisfaction but it can also increase the university productivity. Lawler (1973) defines that the job satisfaction is a multi-dimensional because employees either happy or unhappy. But on the other hand, Smith et al. (1969) also defines that it is a multidimensional. Lee (1988) revealed that job dissatisfaction is the predictor for the turnover. According to Fisher \& Hanna (1931), dissatisfaction resultant into emotional maladjustment.

Job Satisfaction Factors: According to Sokoya (2000) job satisfaction factors includes pay, work, promotion, supervision, environment, and the co-workers. Research results from Santhapparaj \& Alam (2005) indicated that salary, promotion, working condition is directly linked to university academics job satisfaction. Saba \& Zafar (2013) conducted a study in Pakistan and found that compensation, promotional opportunities, job insecurity, working condition, and the work itself has an effect on the private and public university academics job satisfaction. A research result from Bassett (1994), supervisors has an impact to increase the employee's job satisfaction. On the other hand, Ellickson \& Logsdon (2002) conducted a study and their results shows that promotional opportunities have an impact on the employee's job satisfaction. Study conducted by Arnold \& Feldman (1996) indicated from their results that pay, promotion influence the employee's job satisfaction compared to recognition and the achievement. Study by Oshagbemi (1997), Oshagbemi (1999), Oshagbemi (2000), Fields \&Blum (1997), Mueller \& Wallance (1996), Klecker \& Loadman (1999) found from their studies that employee's job satisfaction depends on individual's personal characteristics and characteristics of the job itself. Siddiqui \& Saba (2013) conducted a survey and found that job security have an influence on the university academic job satisfaction. Research results from Luthans (2005) show that pay, promotion, work, supervision, fellow workers are the factors that affect university academics job satisfaction.

A study was conducted by Lacy \& Sheehan (1997) across the eight countries such as Australia, Germany, Hong Kong, Israel, Mexico, Sweden, UK, USA and found that academic job satisfaction factors includes university atmosphere, morale, sense of community, and relationships with colleagues. A study conducted by Castillo \& Cano (2004) and found that the recognition, supervision, and the relationship affect overall university academics job satisfaction. In a study by Mehrabian et al. (2013) conducted a study on 139 faculty members at the Guilan University of Medical Sciences using a questionnaire based survey and their research results shows that the job security ( $4.14 \pm 0.96)$, friendly relationship with colleagues (4.01 $\pm 0.81)$ and finally the technology and technical knowledge (3.99 \pm 0.87$)$ are factors for university academics in terms of job satisfaction. Another study by Việ (2013) on the University of Agriculture and Forestry Ho Chi Minh City (UAF) and the research results indicated that fiscal resources, personal growth and satisfaction, policy and administration affect university academics job satisfaction. Research conducted by Saif et al. (2012) on the 218 university academics from the province of Khyber PakhtunKhwa in Pakistan and their research results shows that university academics job satisfaction factors are pay, work, supervision, promotion, co-workers and environment. In Uganda another study 
conducted by Ssesanga and Garrett (2005) where 182 respondents responses and their results found that co-worker behaviour, supervision and intrinsic facets of teaching factors that affect university academics in terms of job satisfaction. However, in Uganda another study conducted by Kyamanywa (1996) in Uganda's tertiary institutions and found that the job satisfaction factors are incentives, pay packages, leadership styles and finally the condition at the work place. A study was conducted by Mulindwa (1998) on the academic staff at the Polytechnic College, Kyambogo and found that the remuneration is the greatest academic job satisfaction factor. Study conducted by Mehboob et al. (n. d), Castillo \& Cano (2004), and Nadeem (2011) and found that "work itself" is the most academics satisfying factor and on the other hand "policy" or "working condition" is the least satisfying factor for the university academics.

Job Dissatisfaction Factors: A survey was conducted by the Human Science Research Council (HSRC) in South Africa (Afrol News, n.d) on 21358 educators in more than 1714 selected schools and where $97 \%$ of the participants participated in the study. Results from the survey indicated that academics leave organization because of inadequate remuneration, increased workload, lack of career advancement, professional recognition, work policies, and the job insecurity. A study was conducted in Uganda by Ssesanga \& Garrett (2005) and the results from their study shows that academics dissatisfaction are extrinsic factors that includes facets of remuneration, governance, research, promotion, and the working environment. In a study by Hoy \& Miskel (1991) and the results shows that top achievers promoted quickly can resultant into the dissatisfaction among the loyal and intelligent. Arnold \& Feldman (1996) found that temperature, lighting, ventilation; hygiene, noise, working hours, and the resources with the working environment can be the academics job dissatisfaction. Pearson \& Seiler (1983) examined and found that high dissatisfaction with the academics because of fringe benefits, pay, and the performance criteria. Another study by Moses (1986) and results indicated that academics are dissatisfied because of the undervaluing of the teaching excellence in terms of promotion. A study was conducted in UK by Oshagbemi (1997) as cited in Schulze (2006) found that job dissatisfaction university academics causes because of teaching related items and the research related items.

Extrinsic factors are the job dissatisfaction which includes inadequate compensation, increase paperwork, shifts in student characterizes, negative perception of teachers, problematic relationships with student's parents/guardians (Lee, 1972; Perie \& Baker, 1997; Tye \& O'Brien, 2002). In a study by Spears et al. (2000) concluded that job dissatisfaction can be considered as the primary reasons to leave their jobs. According to Hargreaves $(1994)$, Nias $(1989,1996)$ a number of factors that overthrow academics job satisfaction which are related to feeling of loss, disillusionment, vulnerability and negative perceptions of self-worth: the monotony of daily routines, a lack of motivation and discipline on the students' part and a lack of support and appreciation from colleagues and administration (Farber, 1991; Friedman \& Farber, 1992; Travers \& Coooper, 1996; Vandenberghe \& Huberman, 1999). A study conducted by Ssesanga and Garrett (2005) in Uganda and they conducted a survey on the two universities and a total of 182 respondents were drawn and they found that the job dissatisfactory includes remuneration, governance, research, promotion, and working environment. Furthermore, another study conducted by Tizikara (1998) on the university academics and found that academic job dissatisfactions are inadequate instructional materials, teaching space and the number of students in class. Ololube (2006) conducted a study on teachers and found that the teachers are dissatisfied with the educational policies and administration, pay and fringe benefits, material rewards and the advancement.

\section{Methodology}

The main strategy introduced in this paper is to identify the key factors in terms of academics job satisfaction and job dissatisfaction. The identification factors were resultant from the existing literature. The main results of this study was obtained by compiling job satisfaction factors and job dissatisfaction factors. A systematic literature review was done based on the following steps: formulate the review question, devising the search strategy, application of study selection criteria, study design, and the quality appraisal (Croucher et al., 2003).

Formulate the Review Questions: The formulation of the review questions was guided by the systematic review and it provides the focus and boundaries, shapes all aspect of the review process: inclusion and exclusion criteria, the search strategy, amount of the literature reviewed, the quality appraisal, and the synthesis of evidence (Wallace et al., 2005).The review of questions was guided by the following questions: what are the factors that affect in terms of academic job satisfaction and job dissatisfaction? 
Devising the Search Strategy: Search strategy was comprehensive and related to the review question such as satisfaction and dissatisfaction factors for university academics, university academics job satisfaction and dissatisfaction factors, etc.

Application of Study Selection Criteria: Before studies entered into systematic review, the subjected were two filters such as first filter and second filter. The first filter - comprising set of inclusion and exclusion criteria that only relevant and able to address review question that taken through to the second filter (Wallace et al., 2005).

Study Design: Studies included empirical evidence from experimental or observational research which include qualitative research. The study also includes unpublished or published work (Wallace et al., 2005). In this research article, only selected those are directly associated with job satisfaction and job dissatisfaction factors for university academics.

The quality appraisal criteria: Included study met all five necessity elements of the quality appraisal criteria (Wallace et al., 2005), source: (Croucher et al., 2003) for validity and for the trustworthy findings. Articles were selected which were strongly considerable, acceptable, reliable and the empirically valid. Furthermore, it was considered to each study had the good research questions and theory, model or theoretical framework.

\section{Results}

Table 1 shows that university academics job satisfaction factors and dissatisfaction factors are very similar which have drawn from the existing literature but some of the factors are dissimilar with each other. Results shows that university academics job satisfaction factors are more than dissatisfaction factors. This is summarized is as below in Table1:

Table 1: University academics job satisfaction and dissatisfaction factors

\begin{tabular}{ll}
\hline Satisfaction factors & Dissatistion factors \\
\hline Salary , Compensation & Pay \\
Working Condition & Working Environment \\
Opportunity for promotion & Career Opportunity \\
Facilities & Teaching Related Items \\
Individual's/ Personal Characteristics & Research Related Items \\
Administration and Management & Policy and Administration \\
Supervision & Interpersonal Relationship \\
Work itself & Others (low status in the society/high work/ \\
& rude behavior etc.) \\
Others (job security/commitments/workload etc.) & \\
\hline
\end{tabular}

Table 2: University academics job satisfaction and dissatisfaction factors presented using 0's \& 1's

\begin{tabular}{|c|c|c|}
\hline & Satisfaction Factors & Dissatisfaction Factors \\
\hline Salary, Compensation & 1 & 1 \\
\hline Working Condition & 1 & 1 \\
\hline Opportunity for Promotion & 1 & 1 \\
\hline Work itself & 1 & 0 \\
\hline Individual's / Personal Characteristics & 1 & 0 \\
\hline Administration and Management & 1 & 1 \\
\hline Supervision & 1 & 0 \\
\hline Interpersonal Relationship & 0 & 1 \\
\hline $\begin{array}{l}\text { Facilities (Teaching/Research related items) } \\
\text { Others (Job security/commitments/low }\end{array}$ & 1 & 1 \\
\hline status/ rude behaviour etc.) & 1 & 1 \\
\hline
\end{tabular}

$0=$ Factors does not affect satisfaction/dissatisfaction for university academics

$1=$ Factors does affect satisfaction/dissatisfaction for university academics 

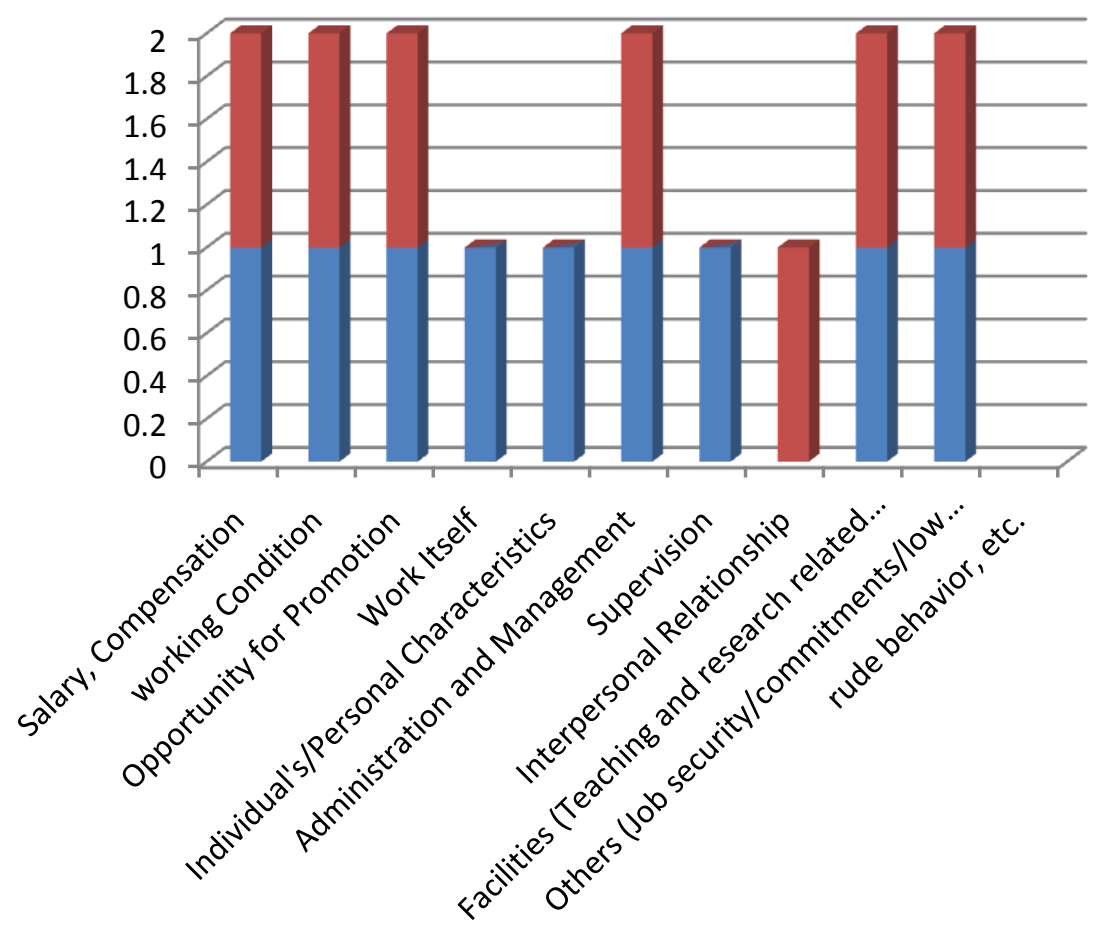

Dissatisfaction Factors

- Satisfaction Factors

Figure 1 is represented in a graphical presentation of the comparison of university academics job satisfaction factors and job dissatisfaction factors.

Figure 2: University academics job dissatisfaction factors

\section{Dissatisfaction Factors}

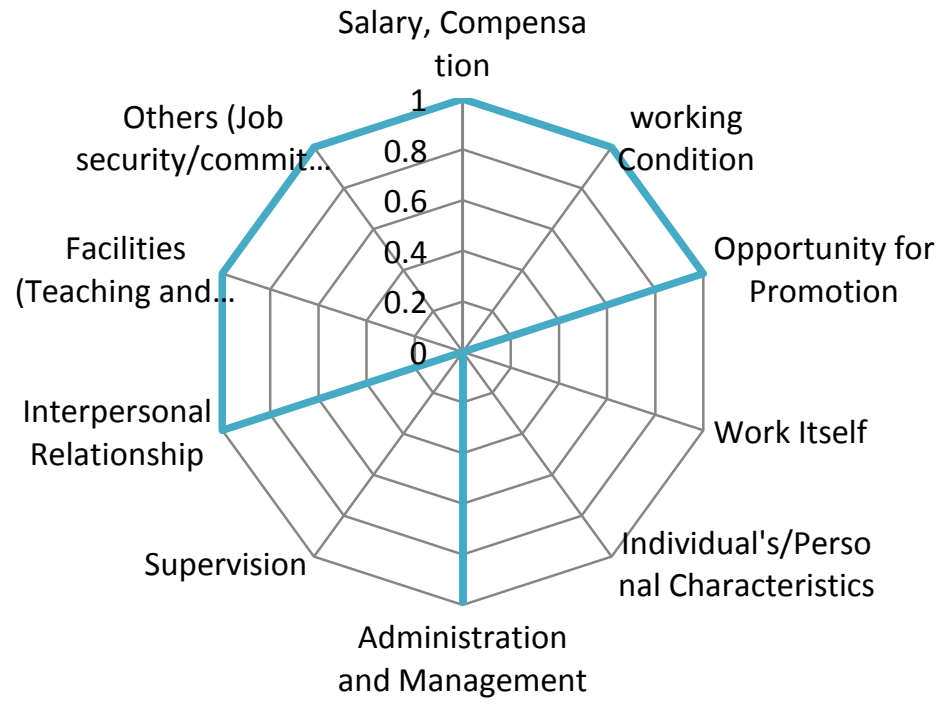

The figure 2 shows that salary and compensation, working condition, opportunity for promotion, administration and management, interpersonal relationship, facilities (teaching and research related items) and others (job security/commitments/low status/rude behaviour etc.) have influence on the 
university academic job dissatisfaction where as work itself, individual's/personal characteristics, supervision have no influence on the university academic job dissatisfaction.

Figure 3: University academics job satisfaction factors

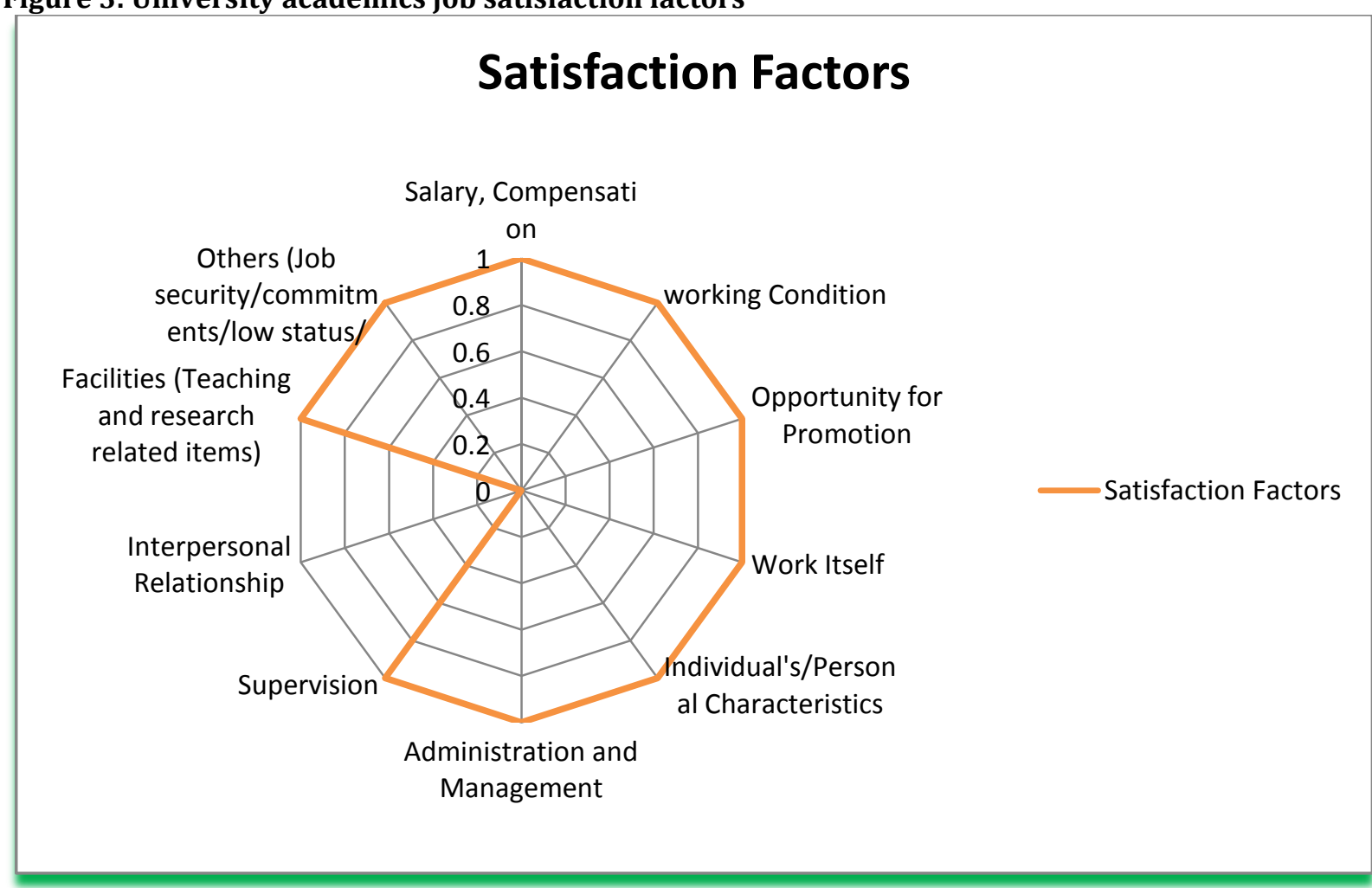

The figure 3 shows that salary and compensation, working condition, opportunity for promotion, administration and management, supervision, facilities (teaching and research related items) and others (job security/commitments/low status/rude behaviour etc.) have influence on the university academic job satisfaction where as interpersonal relationship have no influence on the university academic job dissatisfaction.

\section{Conclusion and Recommendation}

This study however revealed that academic job satisfaction factor and academic job dissatisfaction factor are more or less affect by the university academics. Regardless of which theory is followed job satisfaction factors are salary, compensation; working condition; opportunity for promotion; facilities; individual's/personal characteristics; administration and management; supervision; work itself; others (job security/commitments/workload etc.) and job dissatisfaction factors are pay; working environment; career opportunity; teaching related items; research related items; policy and administration; interpersonal relationship; others (low status in the society/high work/rude behavior etc.). This study has also shown that the satisfaction factors are more than dissatisfaction factors. Lastly, the study has shown that the university academics are more satisfied than dissatisfied.

\section{References}

Adeel, M., Khan, I., Danial, A. H. \& Ahmad, B. (2011). Impact of HR Practices on Job Satisfaction of University Teacher: Evidence from Universities in Pakistan. Industrial Engineering Letters, 1(3), 10-17.

Adenike, A. (2011). Organizational Climate as a Predictor of Employee Job Satisfaction: Evidence from Covenant University. Business Intelligence Journal, 4(1), 157-166.

Afrol News (n.d). Most South African Educators Dissatisfied with Job.

Arnold, H. J. \& Feldman, D. C. (1996). Organizational Behavior. McGraw Hill.

Bassett, G. (1994). The Case against Job Satisfaction. Business Horizons, 37(3), 61-68. 
Castillo, J. \& Cano, J. (2004). Job Satisfaction of Ohio Agricultural Education Teachers. Journal of Agricultural Education, 45(2), 19-27.

Clark, A. E., Georgellis, Y. \& Sanfey, P. (1998). Job Satisfaction, Wage Changes and Quits: Evidence from Germany. Research in Labor Economics, 17.

Croucher, K., Quilgars, D., Wallace, A., Baldwin, S. \& Mather, L. (2003). Paying the Mortgage. A Systematic Literature Review of Safety Nets for Homeowners, York: Department of Social Policy and Social Work.

Denizer, D. (2008). Accidents at Work and Work Related Health Problems by Sex, Status, Age and Severity. Journal of Health Management, 26(2), 721-760.

Ellickson, M. C. \& Longsdon, K. (2002). Determinants of Job Satisfaction of Municipal Government Employees. Public Personnel Management, 31(3), 343-358.

Evans, L. (1998). Teacher Morale, Job Satisfaction and Motivation. London: Paul Chapman, Sage Publication Company.

Feder, B. J. (2000). New York Times. Available from: ProQuest Historical Newspapers. The New York Times (1851-2003). Retrieved on May 10, 2010, from http://www.answers.com/topic/jobenrichment as cited in Ghaffar, A. Ameer, B. Arshad, N. \& Urooj, F. (2013). Factors Affecting Job Satisfaction Level of Academic Staff in Pakistan. Journal of Education and Practice, 4(6), 181-203.

Fields, D. \& Blum, T. (1997). Employee Satisfaction in Work Groups with Different Gender Composition. Journal of Organizational Behavior, 18(2), 181-196.

Farber, B. A. (1991). Crisis in Education: Stress and Burnout in the American Teacher, Jossey-Bass, San Francisco.

Fisher, V. E. \& Hanna, J. V. (1931). The Dissatisfied Worker, 89, 186-186.

Friedman, I. A. \& Farber, B. A. (1992). Professional Self-Concept as a Predictor of Teacher Burnout. Journal of Educational Research, 86(1), 28-35.

Gellatly, I. R. (2005). Individual and Group Determinants of Employee Absenteeism: A Test of a Causal Model. Journal of Organisational Behaviour, 16(1), 469-446.

Hargreaves, A. (1994). Changing Teachers, Changing Times. Cassell, London.

Herzberg, F., Mauser, B. \& Snyderman, B. (1959). The Motivation to Works. New York: John Wiley and Sons.

Hoy, W. K. \& Miskel, C. G. (1991). Educational Administration Theory, Research and Practice. New York: Ramdon House.

Khalid, S., Irshad, M. Z. \& Mahmood, B. (2012). Job Satisfaction among Academic Staff: A Comparative Analysis between Public and Private Sector Universities of Punjab, Pakistan. International Journal of Business and Management, 7(1), 126-136.

Klecker, B. \& Loadman, W. (1999). Male Elementary School Teachers Ratings of Job Satisfaction by Years of Teaching Experience. Education, 119(3), 504-513.

Kyamanywa, T. N. (1996). Factors Affecting Job Satisfaction in Tertiary Institutions in Uganda: A Study of Uganda Polytechnic Kyambogo and National College of Business Nakawa, Unpublished Masters Dissertation, Makerere University.

Lacy, F. J. \& Sheehan, B. A. (1997). Job Satisfaction among Academic Staff: An International Perspective. Higher Education, 34, 305-322.

Lawler, E. E. (1973). Motivation in work Organizations. Brooks/Cool Publishing Company: Monterrey, CA.

Lee, R. (1972). Relationship of Selected Demographic Characteristics and the Job Satisfaction of Industrial Art Teachers (Doctoral dissertation, Missouri University). Dissertation Abstracts International, VT020117.

Lee, T. (1988). How Job Dissatisfaction Leads to Employee Turnover. Journal of Business and Psychology, 2(3), 263-271.

Locke, E. A. (1976). The Nature and Causes of Job Satisfaction. Handbook of Industrial and Organizational Psychology, Rand-McNally, Chicago, IL.

Luthans, F. (2005). Organizational Behavior. McGraw-Hills International Edition.

Mehboob, F., Bhutto, N. Z., Azhar, S. M. \& Butt, F. (n. d). Factors Affecting Job Satisfaction among Faculty Members Herzber's Two Factor Theory Perspective. Asian Journal of Business and Management Sciences, 1(12), 1-9.

Mehrabian, F., Niroumand, E., Mohamadian, S. K., Naghipour, D. (2013). Factors Affecting Job Satisfaction among the Faculty Members at Guilan University of Medical Sciences. Edu R Med S., 2(1), 14-19.

Moses, I. (1986). Promotion of Academic Staff Reward and incentives. Higher Education, 15, 33-37.

Mueller, C. \& Wallace, J. (1996). Justice and the Paradox of the Contented Female Worker. Social Psychology Quarterly, 59(4), 338-349. 
Mulindwa, S. K. (1998). Job Satisfaction among Academic and Administrative Staff in Technical Education Institutions in Uganda: A Case Study of Uganda Polytechnic Kyambogo, Unpublished Master's Dissertation, Makerere University.

Nadeem, M. (2011). Study on Job Satisfaction Factors of Faculty Members at University of Baluchistan. International Journal of Academic Research, 3(1), 267.

Noordin, F. \& Josuff, K. (2009). Levels of Job Satisfaction amongst Malaysian Academic Staff. Asian Social Science, 5(5), 122-128.

Nias, J. (1989). Primary Teachers Talking: A Study of Teaching and Work, Routledge, London.

Nias, J. (1996). Thinking about Feeling: The Emotion in Teaching. Cambridge Journal of Education, 26(3), 293-306.

Odom, R. Y., Boxx, W. R. \& Dunn, M. G. (1990). Organizational Cultures Commitment, Satisfaction, and Cohesion. Public Productivity Management Review, 14(2), 157-168.

Ololube, N. P. (2006). Teachers Job Satisfaction and Motivation for School Effectiveness: An Assessment, Online Submission.

Oshagbemi, T. (1997). The Influence of Rank on the Job Satisfaction in Higher Education. Education and Training, 39, 354-359 as cited in Schulze, S. (2006). Factors Influencing the Job Satisfaction of Academics in Higher Education. SAJHE, 20(2), 318-335.

Oshagbemi, T. (1999). Academics and Their Managers: A Comparative Study in Job Satisfaction. Personnel Review, 28(1/2), 108-123.

Oshagbemi, T. (2000). Correlates of Pay Satisfaction in Higher Education. The International Journal of Educational Management, 14(1), 31-39.

Ostroff, C. (1992). The Relationship between Satisfaction, Attitudes, and Performance: An Organizational Level Analysis. Journal of Applied Psychology, 77(6), 963-974.

Payne, R. L. \& Morrison, D. (2002). The Differential Effects of Negative Affectivity on Measures of Wellbeing Versus Job Satisfaction and Organisational Commitment. Journal of Organisational Behaviour, 24(3), 415-441.

Pearson, D. A. \& Seiler, R. E. (1983). Environmental Satisfiers in Academe. Higher Education, 12, 35-47.

Perie, M. \& Baker, D. (1997). Job Satisfaction among America's Teachers: Effects of Workplace Conditions, Background Characteristics and Teacher Compensation. Washington, D.C.: National Center for Education Statistics.

Redfern, S. H. (2005). Work Satisfaction, Stress, Quality of Care and Morale of Older People in a Nursing Home. Health and Social Care in the Community, 10(6), 512-517.

Rosse, J. G. \& Saturay, S. L. (2004). Individual Differences in Adaptation to Work Dissatisfaction. Presented at the 2004 Meeting of the Western Academy of Management, Anchorage, Alaska.

Saba, I. \& Zafar, O. (2013). Analyzing Job Satisfaction Level of the Academic Staff: A Case Study of Public and Private Universities of Punjab, Pakistan. International SAMANM Journal of Marketing and Management, 1(2), 12-23.

Sagie, A. (2002). Employee Absenteeism, Organisational Commitment and Job Satisfaction: Another Look. Journal of Vocational Behaviour, 52(2), 156-171.

Saif, S. K., Nawaz, A., Jan, F. A. (2012). Predicting Job-Satisfaction among the Academicians of Universities in Kpk, Pakistan. Industrial Engineering Letters, 2(2), 34-45.

Siddiqui, A. \& Saba, I. (2013). Determining the Job Satisfaction Level of the Academic Staff at Tertiary Academic Institutes of Pakistan. International Journal of Information, Business \& Management, $5(3), 42$.

Siegel, L. \& Lane, I. M. (1982). Personnel and Organisational Psychology. Homewood III: Richard D. Irwin, Inc.

Smith, P. C., Kendall, L. M. \& Hulin, C. L. (1969). Measurement of Satisfaction in Work and Retirement. Rand McNally, Chicago, IL.

Smith, W. T. (2007). Job Satisfaction in the United States, Embargoed for Release NORC/University of Chicago. [Online] Available: http://www-news.uchicago.edu/releases/07/pdf/070417.jobs.pdf

Sokoya, S. K. (2000). Personal Predictors of Job Satisfaction for the Public Sector Manager: Implications for Management Practice and Development in a Developing Economy. Journal of Business in Developing Nations, 4(1).

Santhapparaj, A. S. \& Alam, S. S. (2005). Job Satisfaction among Academic Staff in Private Universities in Malaysia. Journal of Social Sciences, 1(2), 72-76.

Santhapparaj, A. S., Srini, V. J. \& Ling, K. L. (2005). Job Satisfaction among Women Managers in Malaysia Automobile Manufacturing Sector. Journal of Applied Sciences, 5(1), 1553-1578.

Spears, M., Gould, K. \& Lee, B. (2000). Who Would Be a Teacher? A Review of Factors Teacher Retention Unit: Teacher Retention Facts and Statistics. CPS Human Resources. 
Ssesanga, K. \& Garrett, R. M. (2005). Job Satisfaction of University Academics: Perspectives from Uganda. Higher Education, 50, 33-56.

Talat, I., Zulifqar, A., Ishfaq, A., Ashfaq, A., Muhammad, S. \& SaherKhushi, M. (2012). Does Compensation and Demographical Variable Influence on Teachers Commitment and Job Satisfaction? A Study of University of the Punjab, Pakistan. International Journal of Business and Management, 7(4), 35-43.

Tizikara, M. K. (1998). Correlates of Academic Staff Satisfaction in Universities in Uganda, Unpublished Master's Dissertation, Makerere University.

Travers, C. J. \& Cooper, C. L. (1996). Teachers under Pressure: Stress in the Teaching Profession, Routledge, London.

Tye, B. B. \& O'Brien, L. (2002). Why Are Experienced Teachers Leaving the Profession? Phi Delta Kappan, 84(1), 24-32.

Vandenberghe, R. \& Huberman, A. M. (1999). Understanding and Preventing Teacher Burnout: A Sourcebook of International Research and Practice. Cambridge, Cambridge University Press.

Việ, V. V. (2013). Factors Affecting Job Satisfaction of Faculty Members. VNU Journal of Social sciences and Humanities, 29(4), 24-29.

Vroom, V. (1964). Work and Motivation. Wiley: New York.

Wallace, A., Bevan, M., Croucher, K., Jackson, K., O'Malley, L. \& Orton, V. (2005). The Impact of Empty, Second and Holiday Homes on the Sustainability of Rural Communities-A Systematic Literature Review. The centre for housing policy, The University of York, 1-142.

Zembylas, M. (2004). Job Satisfaction among School Teachers in Cyprus. Journal of Educational Administration, 42(3), 357-374. 